\title{
Fruit and seed morphology of Korean Ranunculaceae
}

\author{
Woo-Chul Jung and Kweon Heo ${ }^{1 *}$ \\ Jade Botanical Garden, Chuncheon 24464, Korea \\ ${ }^{1}$ Department of Applied Plant Sciences, Kangwon National University, Chuncheon 24341, Korea \\ (Received 5 January 2017; Revised 18 April 2017; Accepted 24 May 2017)
}

\section{한국산 미나리아재비과의 열매 및 종자 형태 \\ 정우철 - 허 권 ${ }^{*}$ \\ 춘천 Jade Botanical Garden, ${ }^{1}$ 강원대학교 생물자원과학부}

\begin{abstract}
Fruit and seed morphological characteristics were investigated in 36 taxa of 20 genera of Korean Ranunculaceae. As a result, fruits were classified as the achene, berry, or follicle type. In the taxa with achene, the presence of trichomes and stoma on the surface of the fruit and a feature in which the endocarp distinctively develops into a one-layer sclereid were considered as useful characteristics. Moreover, in the taxa with follicles, the composition of the seed coat (bitegmic vs. unitegmic), the cell shape of the seed coat, the presence of trichomes, and the type of seed coat were useful for taxonomic characteristics in Korean Ranunculaceae. Based on the fruit and seed characteristics, Adonis is likely to be classified into Helleboroideae rather than Ranunculoideae, as it has bitegmic ovules. In addition, Enemion is similar to Eranthis in unitegmic ovule and the seed coat structure which has non-sclereid exotesta; therefore, it is reasonable to be placed in Helleboroideae. According to the results of this study, more in-depth research is needed regarding the taxonomic positions of Callianthemum and Actaea, which has the only berry fruit type.
\end{abstract}

Keywords: Ranunculaceae, achene, pericarp morphology, seed coat, anatomy

적 요: 한국산 미나리아재비과 20속 36종에 대하여 열매 및 종자 형태를 조사하였다. 그 결과, 먼저 열매는 수과(achene)와 장과(berry) 및 골돌과(follicle)로 분류되었고, 수과를 갖는 분류군에서는 과피 표면에 모용 (trichome)의 발달유무, 기공(stoma)의 존재여부, 그리고 과피 해부형태에서는 내과피가 한 층의 후벽세포로 뚜렷하게 발달하는 특징이 식별 유용형질로 판단되었다. 그리고 골돌과를 갖는 분류군은 종피의 구성(양주 피 vs. 단주피), 종피 표면의 형태, 모용의 발달 유무, 종피 type 등이 분류형질로 유용한 것으로 판단되었다. 조사된 열매 및 종자 형질에 기초하여, 복수초속(Adonis)은 양주피성 배주를 가지므로 단주피성 배주 유집군 인 미나리아재비아과(Ranunculoideae)에서 Helleboroideae아과로 분류되어야 할 것 같다. 또한 나도바람꽃속 (Enemion)의 나도바람꽃은 단주피성 배주와 종피구조(non-sclereid exotesta) 형질에서 만주바람꽃이나 매발톱 꽃, 개구리발톱과는 다른 너도바람꽃속(Eranthis)과 유사하여 Helleboroideae아과로 분류하는 것이 타당할 것 으로 생각된다. 연구결과, 매화바람꽃속(Callianthemum)과 유일한 장과 속인 노루삼속(Actaea)의 분류학적 위 치에 대하여 좀 더 정확한 연구가 필요할 것으로 생각된다.

주요어: 미나리아재비과, 수과, 과피 형태, 종피, 해부학

*Author for correspondence: laurus@kangwon.ac.kr 
미나리아재비과(Ranunculaceae)는 전 세계적으로 약 56 속 2,100 여종이 북반구 온대와 한대지방에 분포하고, 일 부 종이 남반구 고산지대에 분포하는 것으로 알려져 있으 며(Mabberley, 2008), 그 중 44속이 동아시아에 분포한다 (Tamura, 1993). 우리나라에는 20속 104종이 자생하고 있 는 것으로 알려져 있다 (Park et al., 2007). 미나리아재비과 는 다년생 초본이 대부분을 차지하나 1 년생 또는 2 년생 초본으로 지하경이 발달하거나 아관목 또는 덩굴성 식물 도 있다. 꽃은 양성화이고 드물게 단성화이며, 밀선이 발 달하고, 화판은 3-6장으로 악편상이다. 심피는 이생심피 가 대부분이고, 한 개의 심피에 한 개의 배주가 발달하는 특징은 수과(achene)를 갖는 분류군에서 나타나고, 한 개 의 심피 안에 복수의 배주가 발달하는 특징은 골돌과 (follicle)와 장과(berry)를 갖는 분류군에서 나타난다. 종자 는 대부분 배유를 갖고 있으며, 배는 작은 편이다(Tamura, 1993; Park et al., 2007).

지금까지 미나리아재비과에 대한 분류학적 연구는 Langlet (1932)가 핵형분석을 통하여 과내에 염색체가 긴 Ranunculus type (R-type)과 염색체가 짧은 Thalictrum type (T-type)을 인식하였고, 이는 여전히 미나리아재비과의 분 류를 위한 기본형질로 활용되고 있다(Tamura, 1993). Hegnauer (1966)는 화학성분 분석을 통해 isoquinoline alkaloid 성분이 T-type 염색체군에서만 나타나고, R-type 염색체군에서는 나타나지 않는다고 밝히면서 염색체 형 태와 화학성분간의 일치를 언급하였다. Nowicke and Skvarla (1979)는 화분형태 연구를 통하여 대부분의 속에 서 화분표면에 작은 돌기와 작은 구멍들이 발달하는 특징 을 나타내는 데 반하여, Helleborus, Hydrastis, Trollius 속에 서는 이러한 형태가 나타나지 않는다고 하였다. Hoot (1991)는 미나리아재비과의 외부 형태형질 연구를 통하여 T-type 염색체군과 R-type 염색체군으로 나누는 분류체계 를 지지하였고, T-type 염색체군 식물들이 좀 더 원시적인 형질을 나타낸다고 보고하였다. Tamura (1993)는 미나리 아재비과를 Hydrastidoideae, Isopyroideae, Helleboroideae, Ranunculoideae, Thalictroideae의 5아과로 분류하였다. 형 태형질 위주의 식물분류체계의 발전은 분자생물학의 발 전과 더불어 빠르게 진행되어 왔다. Johansson and Jansen (1993)은 chloroplast DNA (cpDNA) 분석을 통하여 기존 분 류체계와 상당부분 일치함을 보고하였으나 Helleboreae족 인 Trollius와 Adonideae족인 복수초속(Adonis)이 기존체계 와는 달리 매우 근연이며, Hydrastis속이 미나리아재비과 의 자매군이라는 견해를 제시하였다. 또한 Helleboreae족인 너도바람꽃속이 Cimicifugeae족의 Actaea, Anemonopsis, Cimicifuga속들과 매우 근연임을 밝혀 기존의 분류체계를 수정하였다(Johansson, 1995). Hoot (1995)는 분자정보를 이 용한 계통분석에서 Hydrastis속은 독립과(Hydrastidaceae)로 분리해야 한다는 견해를 제시하였다. Cai et al. (2009)은 internal transcribed spacer (ITS) 염기서열 분석을 기반으로
하여 Helleborus 속은 Ranunculoideae아과로, 복수초속은 Helleboroideae아과로 옮겨야 하며, Ranunculoideae아과의 매화바람꽃속(Callianthemum)은 미나리아재비과에서 제 외되어야 한다고 보고하였다. 또한 Cai et al. (2010)은 $r b c \mathrm{~L}$ gene 염기서열 분석을 토대로, Caltha속과 Trollius속은 동 일 족에 위치할 수 없고, Trollius 속은 복수초속과 매우 근 연이며, Aquilegia속은 Thalictroideae아과로 옮길 것을 제 시하면서 Tamura (1993)의 분류체계와는 약간 다른 Hydrastidoideae, Coptidoideae, Helleboroideae, Ranunculoideae, Thalictroideae의 5 아과로 분류하였다. 이처럼 형태형질과 분자형질을 이용한 분류체계의 연구에서도 연구자마다 특정분류군에서 약간의 불일치를 보이며, 결론의 어려움 을 간접적으로 시사하고 있다.

한편, 한국산 미나리아재비과의 종자 및 열매에 관한 연 구는 Lee et al. (2003)이 복수초속의 과피를 연구하여 분류 군 모두 과피 표면에 털(trichome)이 존재하며, 세복수초 (A. multiflora)의 수과 표면에 기공이 존재하는 특징으로 분류형질로 사용하였다. 그러나 Son and Ko (2013)는 동아 시아 복수초속을 연구하면서 복수초, 개복수초, 세복수초 모두 수과표면에 기공이 존재하는 것을 밝혀 기존의 Lee et al. (2003)이 언급한 수과 표면의 기공 유무를 종 식별형 질로 활용하기에는 무리가 있다고 하였다. 또한 Park and Park (2008)은 뀡의다리속을 자방에 털이 없는 것, 자방에 선모가 존재하는 것, 자방에 선모와 연모가 동시에 존재 하는 것으로 구분하였고, 과병이 있는 것과 없는 것, 날개 를 가진 것과 능선을 가진 것으로 구분하였다. 미나리아 재비과의 종피형태 연구로는 Heo and Suh (2008)가 동의나 물아족(Calthinae)에 대한 연구를 수행하여 모데미풀속 (Megaleranthis)과 금매화속(Trollius)의 종피 해부구조가 외종피외층형(exotestal type)으로 일치하여 모데미풀속이 금매화속에 포함되어야 할 것을 제시하였다. 이처럼 한국 산 미나리아재비과의 분류군에 대한 열매 및 종자연구는 단편적으로 수행되어 계통분류학적 정보로 이용하기에 는 어려움이 있다.

따라서 본 연구에서는 한국산 미나리아재비과 전체분 류군을 대상으로 열매 및 종자의 형태를 조사하여 분류학 적으로 유용한 형질을 선발하고 선발된 형질들을 기반으 로 분류체계의 개선을 도모하고자 시도하였다.

\section{재료 및 방법}

본 연구에 사용된 미나리아재비과의 실험재료는 1999 년부터 2013년에 걸쳐 우리나라 각 지역에서 직접 채집하 여 석엽표본으로 만들어 표본관에 보관된 재료를 사용하 였고, 직접 채집하지 못한 분류군은 강원대학교 생물학과 의 석엽표본실 $(\mathrm{KWNU})$ 과 일본 경도대학 표본관 $(\mathrm{KYO})$ 의 석엽표본실에서 채집하여 총 20 속 36 분류군을 재료로 사 용하였다(Table 1). 직접 채집한 열매 및 종자는 formalin- 
Table 1. Materials and collection data of the Korean Ranunculaceae used in this study.

\begin{tabular}{|c|c|}
\hline Taxa & Collection data and voucher \\
\hline \multicolumn{2}{|l|}{ Subfamily Helleboroideae Hutch. } \\
\hline Aconitum pseudolaeve Nakai 진범 & Gangwon, Hongcheon, Mt. Garisan, 29 Sep 2006, W. Lee 66581 (KWNU) \\
\hline Aconitum longecassidatum Nakai 흰진범 & Gangwon, Meongju, Sokum River, 18 Sep 1988, W. Lee 4348 (KWNU) \\
\hline Aconitum ciliare DC. 놋젓가락나물 & Gangwon, Chuncheon, Mt. Daeyrongsan, 8 Oct 1975, W. Lee 4245 (KWNU) \\
\hline Actaea asiatica $\mathrm{H}$. Hara 노루삼 & Gangwon, Chuncheon, Mt. Gujeolsan, 3 Jul 2000, K. Неo 1442 (KWNU) \\
\hline Caltha palustris L. var. palustris 동의나물 & Gangwon, Pyeongchang, Mt. Byeongdusan, 26 Jun 2010, K. Heo s.n. (KWNU) \\
\hline Cimicifuga simplex (DC.) Turcz. 촛대승마 & Gangwon, Yanggu, Mt. Daeamsan, 17 Sep 2007, K. Heo s.n. (KWNU) \\
\hline $\begin{array}{c}\text { Cimicifuga dahurica (Turcz. ex Fisch. \& C. A. Mey.) } \\
\text { Maxim. 눈빛승마 }\end{array}$ & Gangwon, Yangyang, Mt. Jobongsan, 18 Sep 2007, K. Heo s.n. (KWNU) \\
\hline Cimicifuga heracleifolia Kom. var. heracleifolia 승마 & Gangwon, Hongcheon, Mt. Munamsan, 28 Sep 1987, K. Yoo 4548 (KWNU) \\
\hline Delphinium maackianum Regel 큰제비고깔 & Gangwon, Taebaek, Mt. Daedeoksan, 14 Aug 2003, K. Yoo 1296 (KWNU) \\
\hline Eranthis stellata Maxim. 너도바람꽃 & Gangwon, Pyeongchang, Mt. Taegisan, 9 May 2003, K. Heo s.n. (KWNU) \\
\hline Eranthis byunsanensis B. Y. Sun 변산바람꽃 & Gyeongnam, Geoje, Mt. Kyeryongsan, 19 Apr 2008, K. Yoo 70269 (KWNU) \\
\hline Megaleranthis saniculifolia Ohwi 모데미풀 & Gangwon, Pyeongchang, Mt. Taegisan, 20 May 1999, K. Нео 333 (KWNU) \\
\hline Trollius ledebourii Miq. 금매화 & China, Heilongjiang Province, Sep 1943, S. Nakao s.n. (KYO) \\
\hline \multicolumn{2}{|l|}{ Subfamily Isopyroideae Tamura } \\
\hline $\begin{array}{c}\text { Aquilegia buergeriana var. oxysepala (Trautv. \& Meyer) } \\
\text { Kitam. 매발톱꽃 }\end{array}$ & Gangwon, Hongcheon, Mt. Oeumsan, $29 \mathrm{Jul}$ 2007, K. Heo s.n. (KWNU) \\
\hline Aquilegia japonica Nakai \& H. Hara 하늘매발톱 & Gangwon, Chuncheon, Provincial arbotetum, 20 May 2010, D. Shin s.n. (KWNU) \\
\hline Enemion raddeanum Regel 나도바람꽃 & Gangwon, Hongcheon, Mt. Gachilbongsan, 6 May 2004, K. Yoo 1783 (KWNU) \\
\hline Isopyrum manshuricum (Kom.) Kom. 만주바람꽃 & Gangwon, Hongcheon, Mt. Daehaksan, 25 May 2010, Heo and Jung s.n. (KWNU) \\
\hline Semiaquilegia adoxoides (DC.) Makino 개구리발톱 & Jeju, Gyorae, 30 Apr 2005, K. Yoo 56895 (KWNU) \\
\hline \multicolumn{2}{|l|}{ Subfamily Ranunculoideae Hutch. } \\
\hline Adonis amurensis Regel \& Radde 복수초 & Gangwon, Hongcheon, Mt. Maenghyonbongsan, 22 Apr 2003, K. Неo s.n. (KWNU) \\
\hline Anemone raddeana Regel 꿩의바람꽃 & Gangwon, Taebaek, Mt. Daedeoksan, 18 May 2003, K. Yoo 1289 (KWNU) \\
\hline Anemone koraiensis Nakai 홀아비바람꽃 & Gangwon, Taebaek, Mt. Daedeoksan, 18 May 2003, K. Yoo 1288 (KWNU) \\
\hline Anemone narcissiflora L. 바람꽃 & Japan, Tadeyama, 26 Aug 2005, W. Lee \& K. Oh 4445 (KWNU) \\
\hline Callianthemum insigne (Nakai) Nakai 매화바람꽃 & Japan, Kitadake, 27 Jul 1933, M. Ghimidgu s.n. (KYO) \\
\hline $\begin{array}{c}\text { Clematis terniflora var. mandshurica (Rupr.) Ohwi } \\
\text { 으아리 }\end{array}$ & $\begin{array}{c}\text { Gyeonggi, Yangpyeong, Mt. Kumwangsan, } 9 \text { Sep 2005, K.T. Yeo \& K. Heo } 4441 \\
\text { (KWNU) }\end{array}$ \\
\hline Clematis terniflora DC. 참으아리 & $\begin{array}{c}\text { Gangwon, Chuncheon, Namsan, Baekyang, } 26 \text { Oct 2005, K.T. Yeo \& K. Heo } 4507 \\
\text { (KWNU) }\end{array}$ \\
\hline Hepatica asiatica Nakai 노루귀 & Chungnam, Anmyeoon, Ggotji, 18 May 2005, K.T. Yeo \& K. Heo 3872 (KWNU) \\
\hline Hepatica insularis Nakai 새끼노루귀 & $\begin{array}{c}\text { Jeonnam, Yoosu, Dorsan, Sanghwangbong, } 24 \text { Apr 2003, K.T. Yeo \& K. Heo } 3572 \\
\text { (KWNU) }\end{array}$ \\
\hline Hepatica maxima Nakai 섬노루귀 & Gyeongbuk, Ulleung-do, 22 Jun 2007, K. Heo s.n. (KWNU) \\
\hline $\begin{array}{c}\text { Pulsatilla koreana (Y. Yabe ex Nakai) Nakai ex Mori } \\
\text { 할미꽃 }\end{array}$ & Gangwon, Chuncheon, Mt. Kumbeongsan, 11 May 2007, Yoo 62678 (KWNU) \\
\hline $\begin{array}{c}\text { Pulsatilla tongkangensis Y. N. Lee \& T. C. Lee } \\
\text { 동강할미꽃 }\end{array}$ & Gangwon, Yeongwol, Donggang River, 20 May 2009, K. Heo s.n. (KWNU) \\
\hline Ranunculus japonicus Thunb. 미나리아재비 & Gangwon, Pyeongchang, Mt. Byengdusan, 23 Aug 2010, K. Heo s.n. (KWNU) \\
\hline $\begin{array}{c}\text { Ranunculus quelpaertensis (H. Lev.) Nakai } \\
\text { 왜젓가락나물 }\end{array}$ & Gangwon, Chuncheon, Upper center-land, 23 Jun 2006, K. Yoo 67257 (KWNU) \\
\hline \multicolumn{2}{|l|}{ Subfamily Thalictroideae Heintze } \\
\hline $\begin{array}{c}\text { Thalictrum aquilegifolium var. sibiricum Regel \& Tiling } \\
\text { 뀡의다리 }\end{array}$ & Gangwon, Hoengseong, Gigu, 21 Jul 1993, K. Heo 2625 (KWNU) \\
\hline Thalictrum uchiyamai Nakai 자주꿩 의다리 & Jeonbuk, Wanju, Mt. Daedunsan, 7 Oct 2004, K. Yoo 1845 (KWNU) \\
\hline $\begin{array}{c}\text { Thalictrum rochebrunianum var. grandisepalum Nakai } \\
\text { 금꿩의다리 }\end{array}$ & Gangwon, Hoengseong, Gigu, 8 Aug 2005, K. Yoo 56880 (KWNU) \\
\hline $\begin{array}{c}\text { Thalictrum filamentosum var. tenerum (Huth) Ohwi } \\
\text { 산꿩의다리 }\end{array}$ & Gangwon, Hoengseong, Mt. Cheongtaesan, 13 Aug 2003, K. Нео 2733 (KWNU) \\
\hline
\end{tabular}


acetic acid-alcohol 용액에 3일 이상 고정하였고. 석엽표본 에서 채집한 실험재료는 먼저 $3 \%$ 암모니아수에 하루 동 안 침지하여 원형회복 과정을 거친 후 실험에 사용하였다. 기본적으로 종자의 횡단면 구조를 관찰하는 것으로 하였 으며, 열매의 종류가 수과인 것은 종자표면을 관찰하기 어려워 이들 분류군은 과피 표면 및 과피 해부구조를 중 심으로 비교 연구하였고, 종피형태는 과피와 함께 절단면 을 만들어 관찰하였다. 먼저 성숙 과피 및 종자는 크기를 고려하여 원활한 탈수를 위하여 열매의 일부분을 잘라내 고 에탄올 series로 각각 24시간 탈수 후, Technovit 7100 (Kultzer, Wehrheim, Germany) 수지에 포매하여 block을 제 작하였으며, rotary microtome을 이용하여 두께 4-5 $\mu \mathrm{m}$ 로 횡단면 절단하여 슬라이드 위에 고정시킨 후 $1 \%$ Toludine blue $\mathrm{O}$ 용액으로 염색하고, Entellan으로 mounting하여 영 구표본을 제작하였다. 제작한 슬라이드는 광학현미경 (BX-50, Olympus Co., Tokyo, Japan)으로 관찰하고 부착된 디지털카메라로 사진을 촬영하였다. 또한, 과피(수과) 및 종피(골돌과)의 표면 형질을 관찰하기 위하여 열매(수과) 및 종자를 에탄올 series로 탈수 후 t-butyl alcohol 용액으로 치환하였다. 치환된 열매 및 종자는 동결건조기(Freeze Drying Device: JEOL JFD-320, Tokyo, Japan)로 건조한 뒤, 이온증착기(E-1010, Hitachi Co., Tokyo, Japan)로 $5 \mathrm{~mA}$ 에서 3 분간 금 $(\mathrm{Au})$ 으로 코팅하여 주사전자현미경(JEOL JSM$6490 \mathrm{LV}$ )으로 $15-20 \mathrm{kV}$ 하에서 관찰하고 사진을 촬영하였 다. 열매 및 종자에 대한 기재용어는 Corner (1976)와 Spjut (1994)를 따랐다.

\section{결 과}

\section{열매 및 종자의 해부형태}

기본적으로 미나리아재비과 내에서 과피와 종피가 잘 분리되지 않는 수과는 과피 표면과 과피벽 횡단면 해부특 징을, 골돌과는 종자의 표면형태와 횡단면 해부형태를 중 심으로 조사하였으며, 아래에 그 특징을 아과별로 기재하 였다.

\section{Subfamily Helleboroideae Hutch.}

진범속(Aconitum L.): 놋젓가락나물(A. ciliare), 흰진범 (A. longecassidatum), 진범(A. pseudolaeve var. erectum) 3 종 을 관찰하였다(Figs. 1A-I). 열매는 골돌(follicle)이다. 종자 형태는 길이가 약 3-4 mm, 폭이 약 2-4 mm의 크기를 가진 다. 한쪽 면에서 길게 발달한 날개는 막 구조이며(Figs. 1A, $\mathrm{D}, \mathrm{G})$, 주름진 날개 표면에는 미세돌기(fine granulated)가 존재한다(Figs. 1B, E, H). 종자는 외주피와 내주피를 갖는 양주피성 배주(bitegmic ovule)이다. 종자의 횡단면 구조는 외종피외층(exotesta)이 날개상으로 발달하지만 외종피내 층(endotesta)이 한 층의 후벽세포로 발달하는 외종피내층 형(endotestal type)이다. 외종피중층(mesotesta)은 1-2개의
세포층으로 구성되나, 내종피(tegmen)와 함께 퇴화하였다 (Figs. 1C, F, I).

노루삼속(Actaea L.): 노루삼(A. asiatica)의 열매종류는 장과로 과실 당 4 개의 종자가 모여 있어 두 면은 편평하고 한쪽 면은 굴곡진 형태로 삼각형에 가깝다. 종자의 크기 는 길이 약 $3.5 \mathrm{~mm}$, 폭 약 $3.0 \mathrm{~mm}$ 이며, 표면은 표피세포가 다각형으로 볼록 튀어나온 망상(reticulate) 형태를 하고 있 다(Figs. 1J, K). 양주피성 배주로 내주피는 2 세포층의 두 께, 외주피는 4-5세포층 두께이다. 종피의 횡단면 구조를 보면 tannin을 조금 함유한 한 층의 세포층으로 이루어진 외종피외층과 6 개의 세포층으로 비대해진 외종피중층이 존재하며 나머지 부분은 퇴화한 형태였다(Fig. 1L).

동의나물속(Caltha L.): 동의나물(C. palustris var. palustris) 은 양주피성 배주이다. 종자는 검은색 타원형으로 한쪽 가장자리에 raphe bundle이 관찰된다(Fig. 2M). 외종피외층 이 후벽세포의 책상조직 형태로 발달하며 많은 tannin을 함유하고 있는 외종피외층형이다(Fig. 2O). 종피의 표면 은 매끈하며, 표피세포는 긴 입방체모양이다(Fig. $2 \mathrm{~N}$ ).

승마속(Cimicifuga Wernisch.): 눈빛승마(C. dahurica), 승마(C. heracleifolia var. heracleifolia), 촛대승마(C. simplex) 3 종을 관찰하였다(Figs. 2D-L). 열매의 종류는 골돌과이다. 종자는 길이 약 $3.0 \mathrm{~mm}$, 폭 $1.5-3 \mathrm{~mm}$ 의 크기를 가지는 타 원형이다(Figs. 2D, G, J). 전체에 막으로 이루어진 날개 (wing)는 지름방향으로 길게 발달하였고, 날개는 굴곡진 형태로 미세돌기가 존재하는 특징을 가지고 있다(Figs. $2 \mathrm{E}, \mathrm{H}, \mathrm{K})$. 배주는 외주피, 내주피 모두 존재하는 양주피성 이다. 종피의 횡단면은 외종피외층은 1-2개의 세포층으 로 이루어져 있으며, 외종피외층 세포가 풍선처럼 팽창하 여 날개모양으로 발달하는 외종피외층형이다. 외종피중 층은 쭈그러져있고, 외종피내층, 내종피는 압축된 형태로 퇴화하여 흔적만 남아 있다(Figs. $2 \mathrm{~F}, \mathrm{I}, \mathrm{L})$.

제비고깔속(Delphinium L.): 큰제비고깔(D. maackianum) 의 종자는 길이 약 $2 \mathrm{~mm}$, 폭은 약 $1.5 \mathrm{~mm}$ 로 타원형이며, 전 체에 막으로 이루어진 작은 날개로 되어 있고, 날개는 주 름형태로 미세돌기가 존재한다(Figs. $3 \mathrm{~A}, \mathrm{~B}$ ). 배주는 외주 피와 내주피를 갖는 양주피성 배주이다. 종자의 횡단면은 외종피외층이 날개처럼 발달하였고, 외종피중층은 1-2개 의 세포층을 이루고 있으며, 외종피내층은 섬유상의 후벽 세포로 발달하여 외종피내층형이었다(Fig. $3 \mathrm{C}$ ). 내종피층 은 쭈그러져 퇴화하였다.

너도바람꽃속(Eranthis Salisb.): 변산바람꽃(Er. byunsanensis)과 너도바람꽃(Er. stellata)의 종자를 관찰하였다 (Figs. 3D-I). 두 종의 종자는 둥근 형태로 직경은 약 $2.0 \mathrm{~mm}$ 정도이다. 종자표면은 전체적으로 매끈하거나 주 름진 모양을 하고 있으며, 표피세포는 망상모양을 하고 있다(Figs. $3 \mathrm{E}, \mathrm{G})$. 변산바람꽃은 세포 경계의 세포벽이 약 간 위로 돌출하는 양상으로 차이가 있었다(Fig. 3G). 또한, 종자의 횡단면 구조를 보면, 뚜렷한 형태적 차이로 표면 
에 길이 약 40-50 $\mu \mathrm{m}$ 정도의 표피세포 유래의 단세포 모 용(unicellular hair)이 발달한다는 점에서 너도바람꽃과 큰 차이점을 나타냈다(Fig. $3 \mathrm{H})$. 변산바람꽃 종자는 건조표 본으로부터 채집한 재료인 관계로 외종피외층이 대부분 찌그러진 모양을 하고 있고, 모용도 거의 누워 있는 상태
로 관찰되었다(Fig. 3G, I). 두 종의 종피 해부학적 특징을 보면, 종피는 외종피(testa)만으로 구성되는 단주피성 배 주(unitegmic ovule)이다. 그 중에서도 외종피외층이 종피 의 대부분을 차지하고 나머지 층은 퇴화한 구조로 외종피 외층형이다.
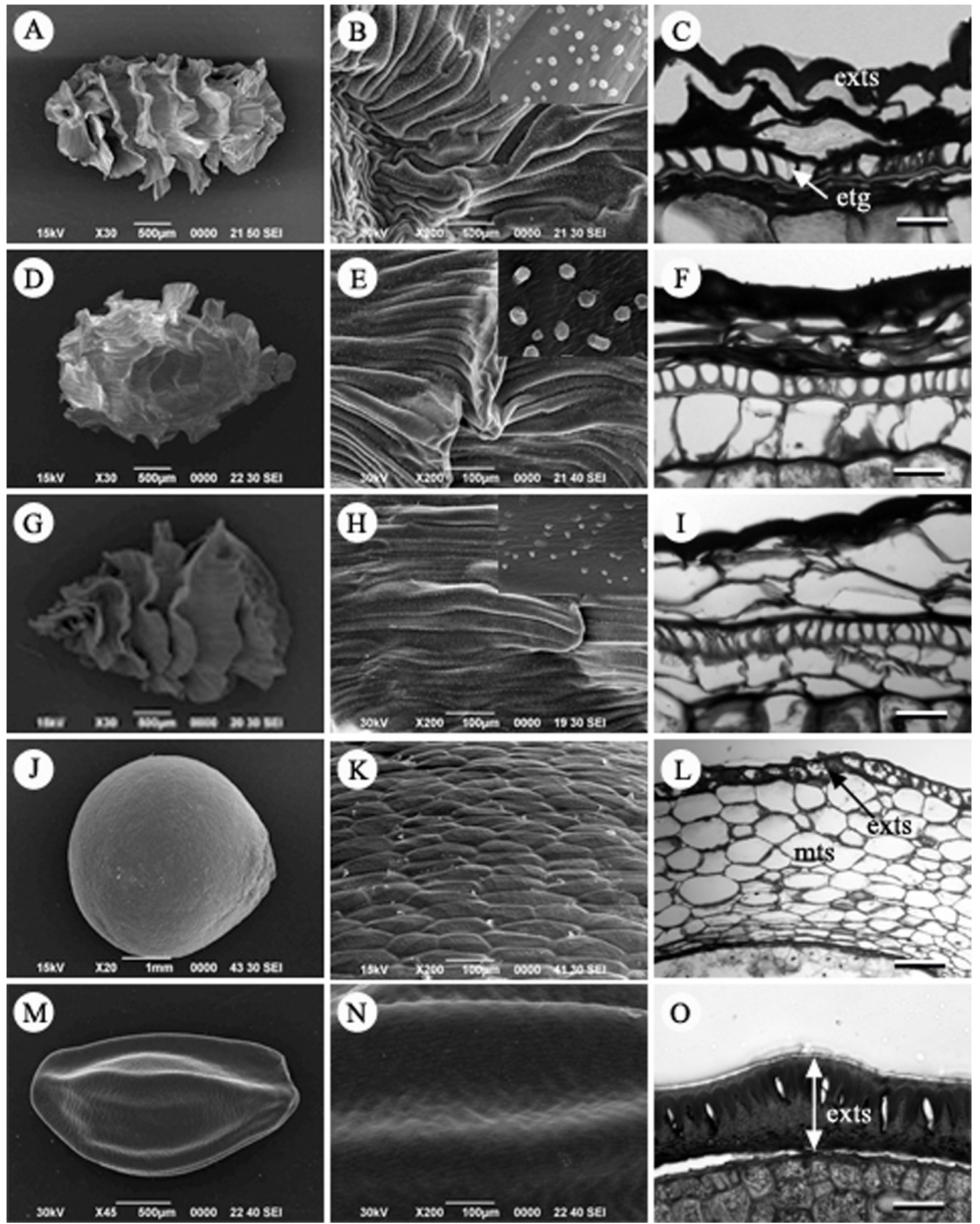

Fig. 1. Seed, seed surface and seed coat structure in Korean Ranunculaceae. A-C. Aconitum ciliare. D-F. A. longecassidatum. G, H. A. pseudolaeve. J-L. Actaea asiatica. M-O. Aquilegia japonica. exts, exotesta; etg, endotesta; mts, mesotesta. Scale bars $=50 \mu \mathrm{m}$. 
모데미풀속(Megaleranthis Ohwi): 모데미풀(M. saniculifolia) 종자는 검은색을 띠고 있으며 장타원형이다(Fig. $4 \mathrm{~A})$. 배주는 외주피와 내주피로 구성되는 양주피성 배주 이다. 종피는 외종피외층형으로서 외종피외층에 많은 tannin을 함유하고 있고, 성숙할수록 외종피의 가장 바깥 층(외종피외층)은 대보강세포 형태의 후벽세포로 발달하 고, 외종피내층과 내종피층들은 퇴화하여 흔적만 남는다 (Fig. 4C). 종자표면의 표피세포는 망상이며 입방체 모양
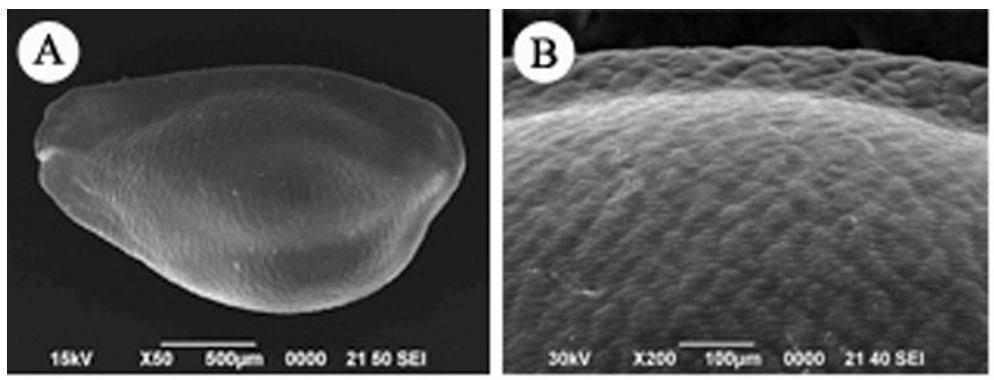

C
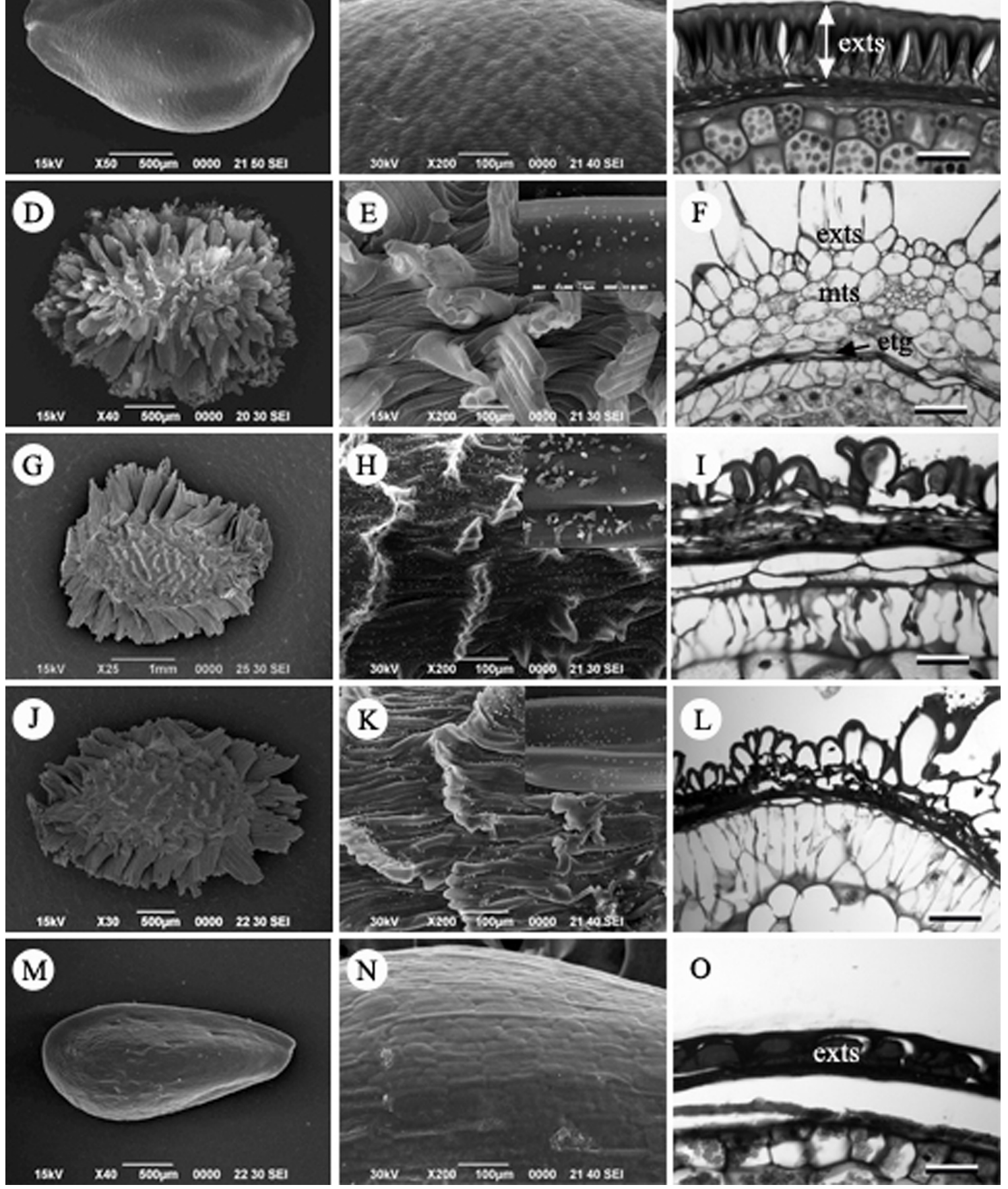

Fig. 2. Seed, seed surface and seed coat structure in Korean Ranunculaceae. A-C. Aquilegia buergeriana var. oxysepala. D-F. Cimicifuga simplex. G, H. C. heracleifolia var. heracleifolia. J-L. C. dahurica. M-O. Caltha palustris var. palustris. exts, exotesta; mts, mesotesta; etg, endotegmen. Scale bars $=50 \mu \mathrm{m}$. 
으로 중앙이 약간 함몰된 형태를 나타냈다(Fig. 4B).

금매화속(Trollius L.): 금매화(T. ledebourii) 종자는 검은 색으로 장타원형이다(Fig. 5D). 종자의 표면은 약간 울퉁 불퉁하며 표피세포는 망상구조이다(Fig. 5E). 배주는 내.
외주피로 구성되는 양주피성 배주이다. 종피는 외종피외 층이 대보강세포 형태의 후벽세포로 발달하며 tannin을 함유하고 있는 외종피외층형이다. 내종피층은 성숙 종자 시기에 완전히 퇴화하였다(Fig. $5 \mathrm{~F}$ ).
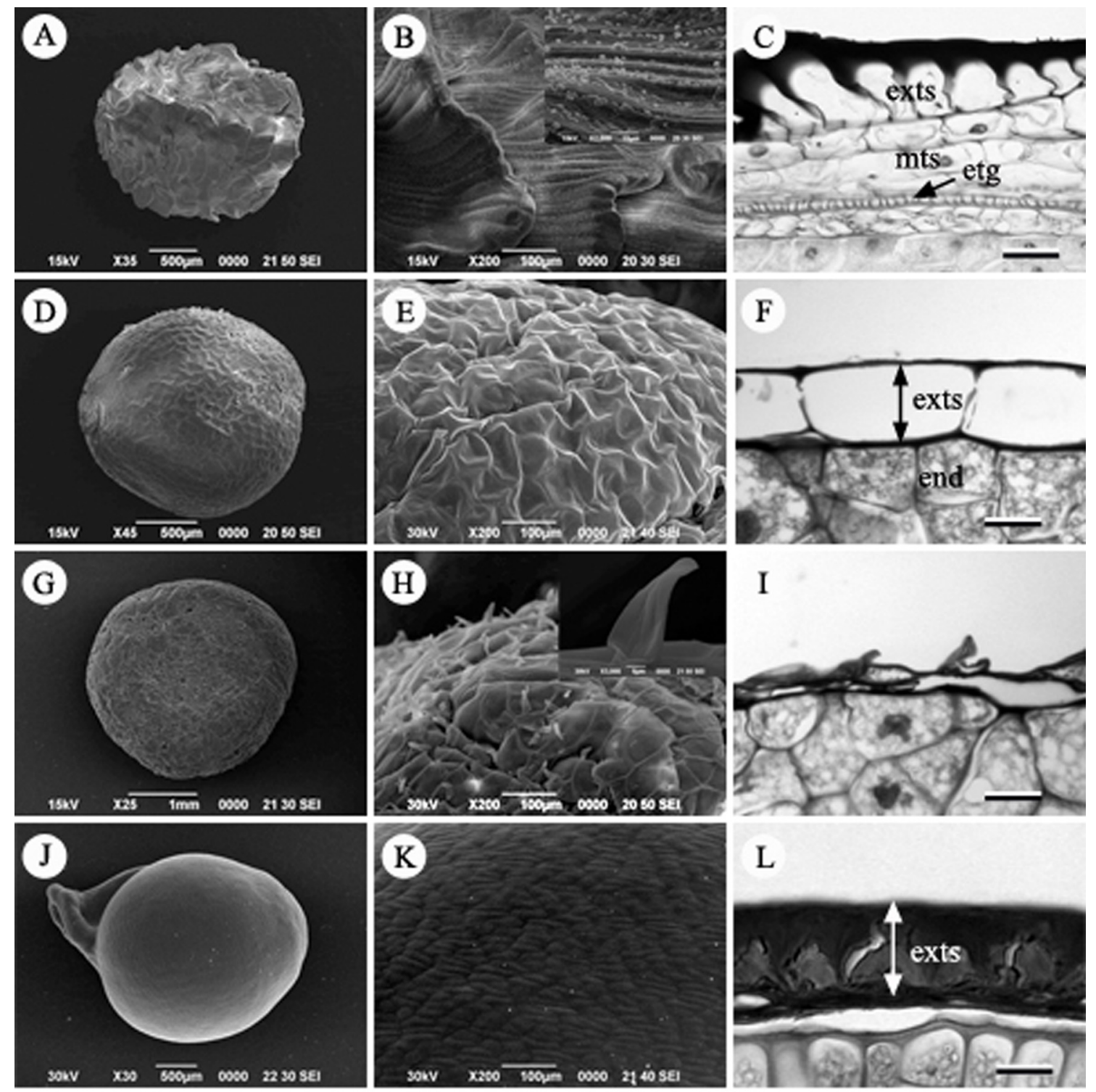

$\mathrm{L}$
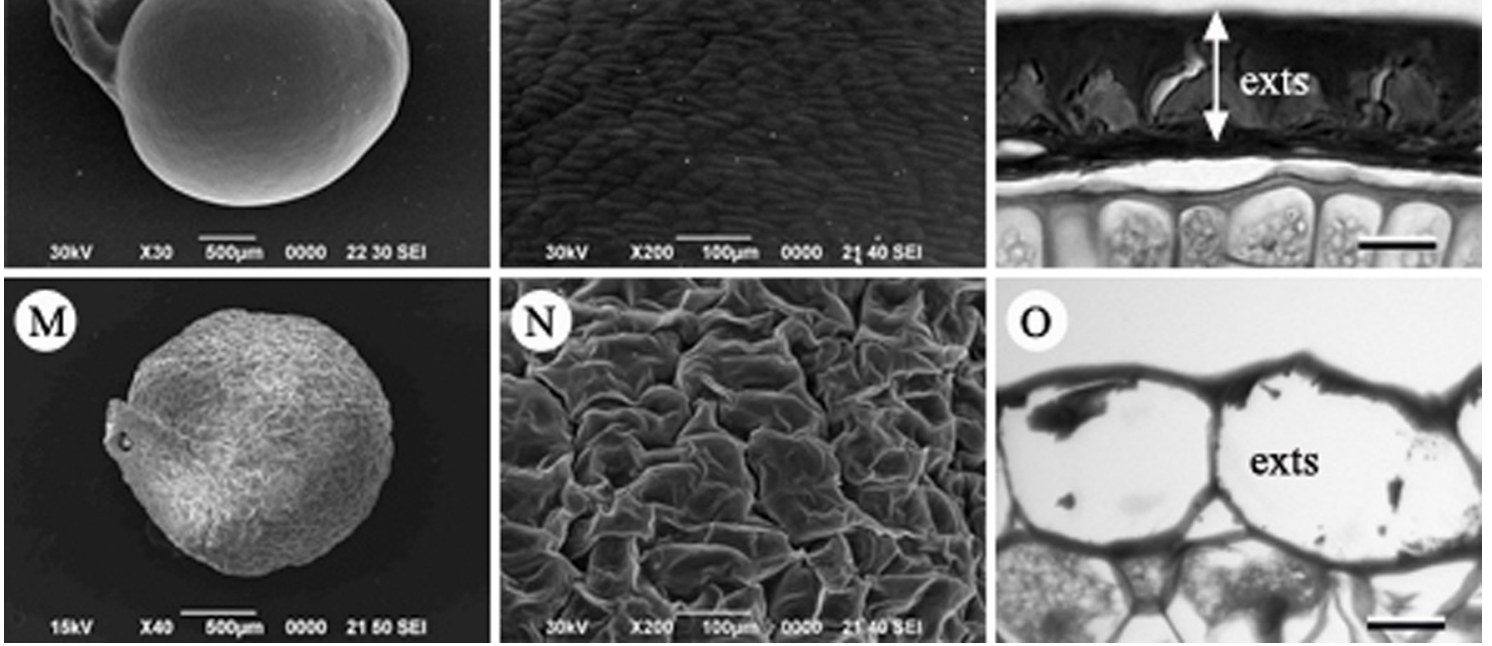

Fig. 3. Seed, seed surface and seed coat structure in Korean Ranunculaceae. A-C. Delphinium maackianum. D-F. Eranthis stellata. G-I. Er. byunsanensis. J-L. Isopyrum manshuricum. M-O. Enemion raddeanum. exts, exotesta; mts, mesotesta; etg, endotegmen; end, endosperm. Scale bars $=50 \mu \mathrm{m}$. 


\section{Subfamily Isopyroideae Tamura}

매발톱꽃속(Aquilegia L.): 매발톱꽃(A. buergeriama var. oxysepala $)$ 과 하늘매발톱(A. japonica) 2종을 관찰하였다. 종자는 난형으로 한쪽 가장자리에는 raphe bundle이 있다
(Figs. 1M, 2A). 표면은 볼록하지만 전체적으로 매끈하다 (Figs. 1N, 2B). 양주피성 배주로 외종피외층은 tannin을 함유하고 있고, 책상조직 형태의 후벽세포로 발달하는 외종피외층형이다. 내종피는 성숙과정에서 퇴화하였다
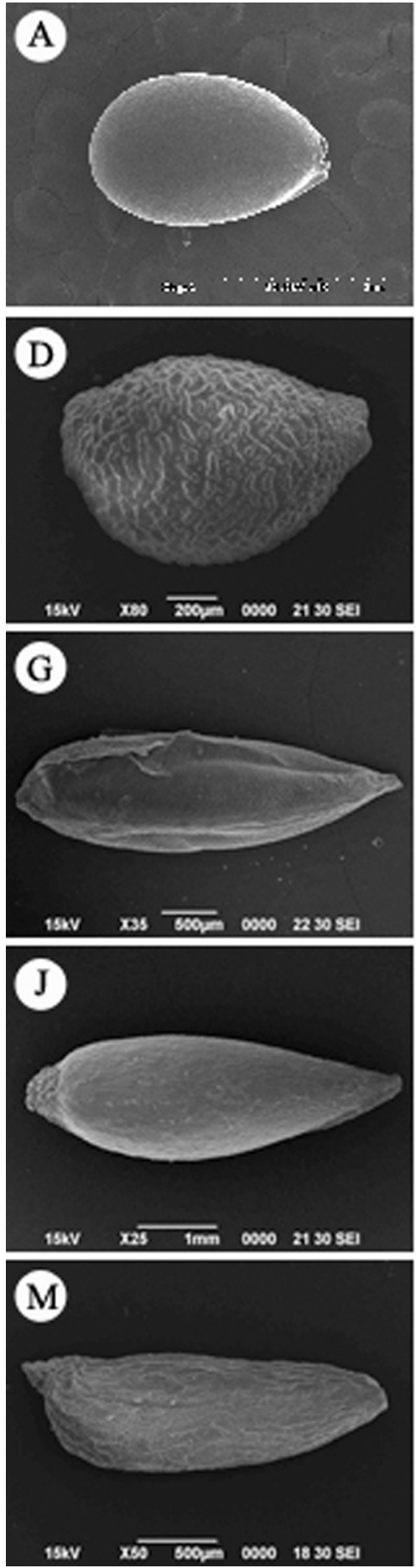
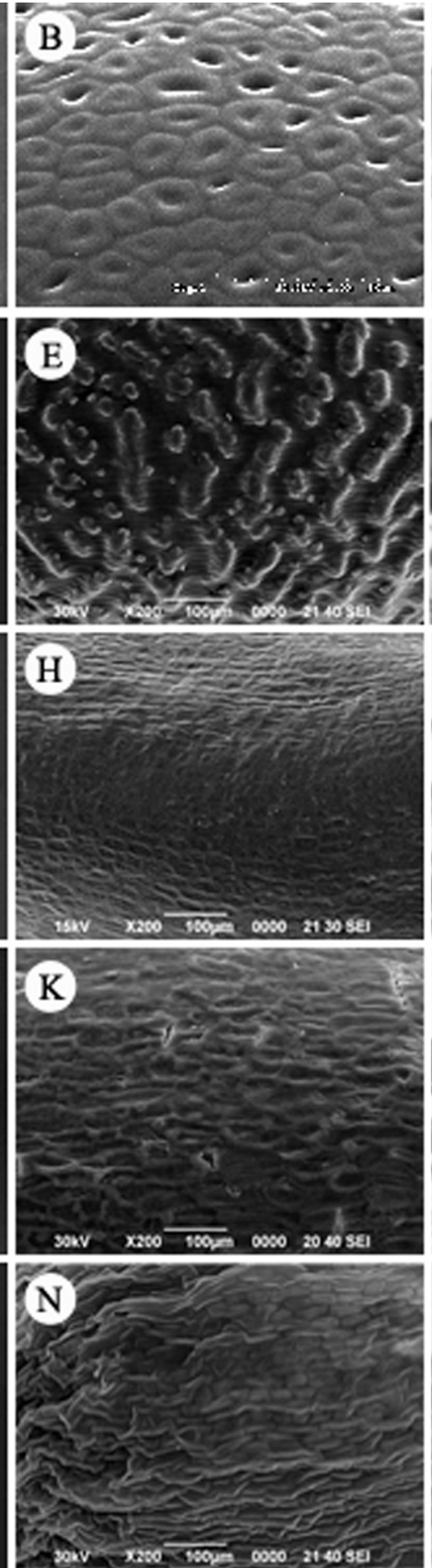

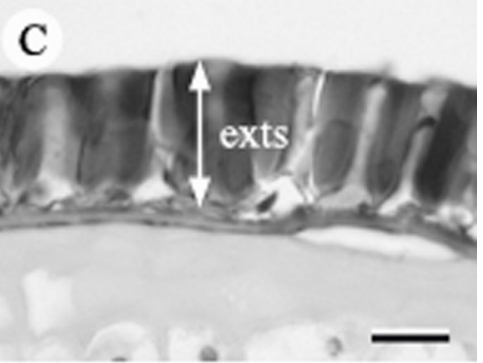

F
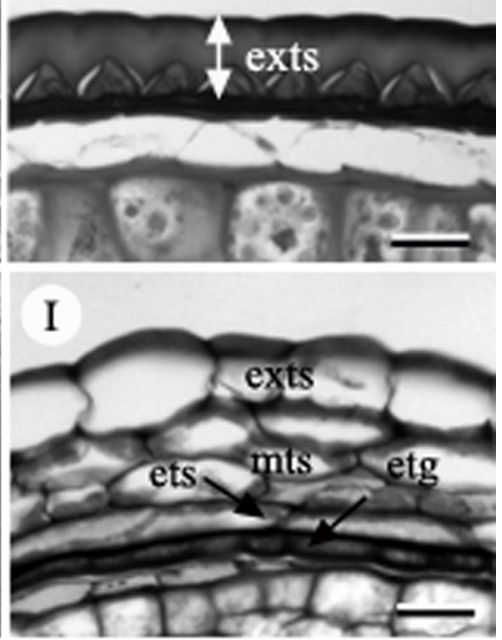

$\mathrm{L}$
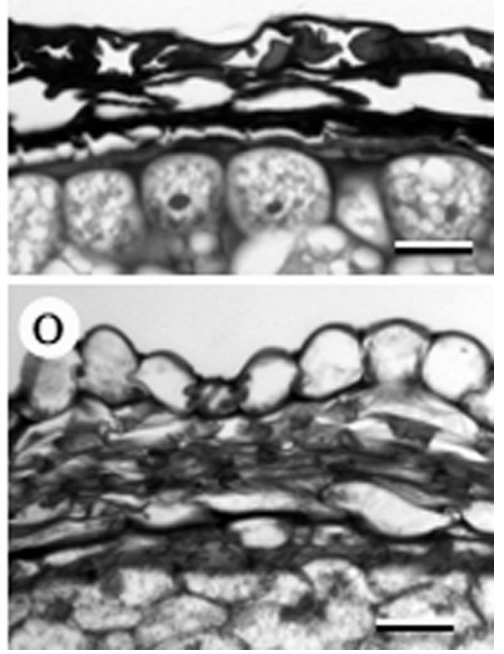

Fig. 4. Seed, seed surface and seed coat structure in Korean Ranunculaceae. A-C. Megaleranthis saniculifolia. D-F. Semiaquilegia adoxoides. G-I. Thalictrum filamentosum var. tenerum. J-L. T. aquilegifolium var. sibiricum. M-O. T. rochebrunianum var. grandisepalum. exts, exotesta; ets, endotesta; mts, mesotesta; etg, endotegmen. Scale bars $=50 \mu \mathrm{m}$. 
(Figs. 1O, 2C).

나도바람꽃속(Enemion Raf.): 나도바람꽃(En. raddeanum) 의 종자는 원형으로 지름이 약 $2.0 \mathrm{~mm}$ 정도이다. 종자표 면은 전체적으로 주름진 모양을 하고 있으며, 표피세포는 망상모양을 하고 있다(Figs. $3 \mathrm{M}, \mathrm{N}$ ). 종피는 외종피만으로 구성되어 있었고(단주피성 배주), 그 중에서 외종피외층 이 종피의 대부분을 차지하였으며, 나머지는 퇴화한 구조 였다(Fig. 3O).

만주바람꽃속(Isopyrum L.): 만주바람꽃(I. manshuricum) 1 종을 관찰하였다. 만주바람꽃의 종자는 원형으로 지름 이 약 $3.0 \mathrm{~mm}$ 정도이다(Fig. $3 \mathrm{~J})$. 종자의 표면은 전체적으 로 매끈하며, 표피세포는 긴 입방체 모양이다(Fig. $3 \mathrm{~K}$ ). 양 주피성 배주이며, 종피는 외종피외층형으로서 외종피외 층은 책상조직 형태의 후벽세포로 발달하고 많은 tannin 을 함유하고 있다(Fig. 3L). 성숙할수록 외종피외층만 남 고, 외종피중층, 외종피내층과 내종피 층들은 퇴화하여 흔적만 남아있다(Fig. 3L).

개구리발톱속(Semiaquilegia Makino): 개구리발톱 $(S$. adoxoides)의 종자는 길이 약 $1.2 \mathrm{~mm}$, 폭은 약 $0.8 \mathrm{~mm}$ 로 타 원형이며, 종자의 표면은 주름이 있으며 혹 모양의 돌기 가 줄지어 모여 있다(Figs. 4D, E). 양주피성 배주로, 외종 피외층이 대보강세포 형태의 후벽세포로 발달하고 많은 tannin을 함유하고 있는 외종피외층형이다. 그 외 외종피 중층, 외종피내층, 내종피층은 퇴화하여 흔적만 남는다 (Fig. 4F).

\section{Subfamily Ranunculoideae Hutch.}

복수초속(Adonis L.): 복수초(A. amurensis)는 수과이며, 향축으로 구부러진 암술대를 갖고 있고 전체에 털이 밀생
한다(Fig. 6A). 열매 표면에 기공이 관찰된다. 양주피성 배 주로 내주피는 2층, 외주피는 4-6개의 세포층 두께이다. 외종피는 비대해지지만 특수화하지 않는 unspecialized seed coat type으로 7-8개의 세포층 두께로 비후되고, 내종 피는 퇴화하였다(Fig. 6C).

매화바람꽃속(Callianthemum C. Meyer): 매화바람꽃 (C. insigne)은 수과이며, 향축으로 구부러진 암술대를 갖 고 있고 표면은 털이 없고, 쭈그러져 있다(Figs. 6D, E). 과 피는 후벽세포로 구성된 한 층의 내과피(endocarp)와 과피 의 대부분을 차지하는 중과피, 그리고 여러 층의 유세포 로 구성되어 성숙시에는 쭈구러진 외과피로 구성된다. 특 히, 중과피는 7-8 세포층의 후벽세포로 발달하여 과피벽 의 대부분을 차지하였다(Fig. 6F). 종피 구조는 정확히 확 인할 수 없었다.

노루귀속(Hepatica Miller): 노루귀(H. asiatica)와 새끼노 루귀(H. insularis)는 수과로 길이가 약 $4.5 \mathrm{~mm}$, 폭은 약 $2.0 \mathrm{~mm}$ 로 타원형 또는 난형이다(Figs. 6G, J). 수과의 표면 은 주름진 형태로 긴 털이 많이 분포하고 있고 비기능성 기공이 존재하는 특징이 있다(Figs. $6 \mathrm{H}, \mathrm{K})$. 반면에, 섬노루 귀(H. maxima)는 다른 종과 같이 비기능성 기공이 존재하 지만 수과의 크기가 상대적으로 크며(길이 약 $6.5 \mathrm{~mm}$, 폭 약 $3.5 \mathrm{~mm}$ ), 표면은 편평하고 털이 없으며, 표피세포가 다 각형으로 뚜렷이 구분되는 것이 다른 종과 구별되는 특징 이었다(Figs. 6M, N). 종자의 횡단면구조는 내종피가 없으 며, 외종피만으로 구성된 단주피성 배주이다. 외종피외층 이 1-2층의 세포층 두께를 가지며, 특징적인 형태로 분화 하지 않는 unspecialized seed coat type이다. 외종피중층은 쭈그러지고, 외종피내층은 압축되어 얇은 층으로 존재한 다(Figs. 6I, L, O).
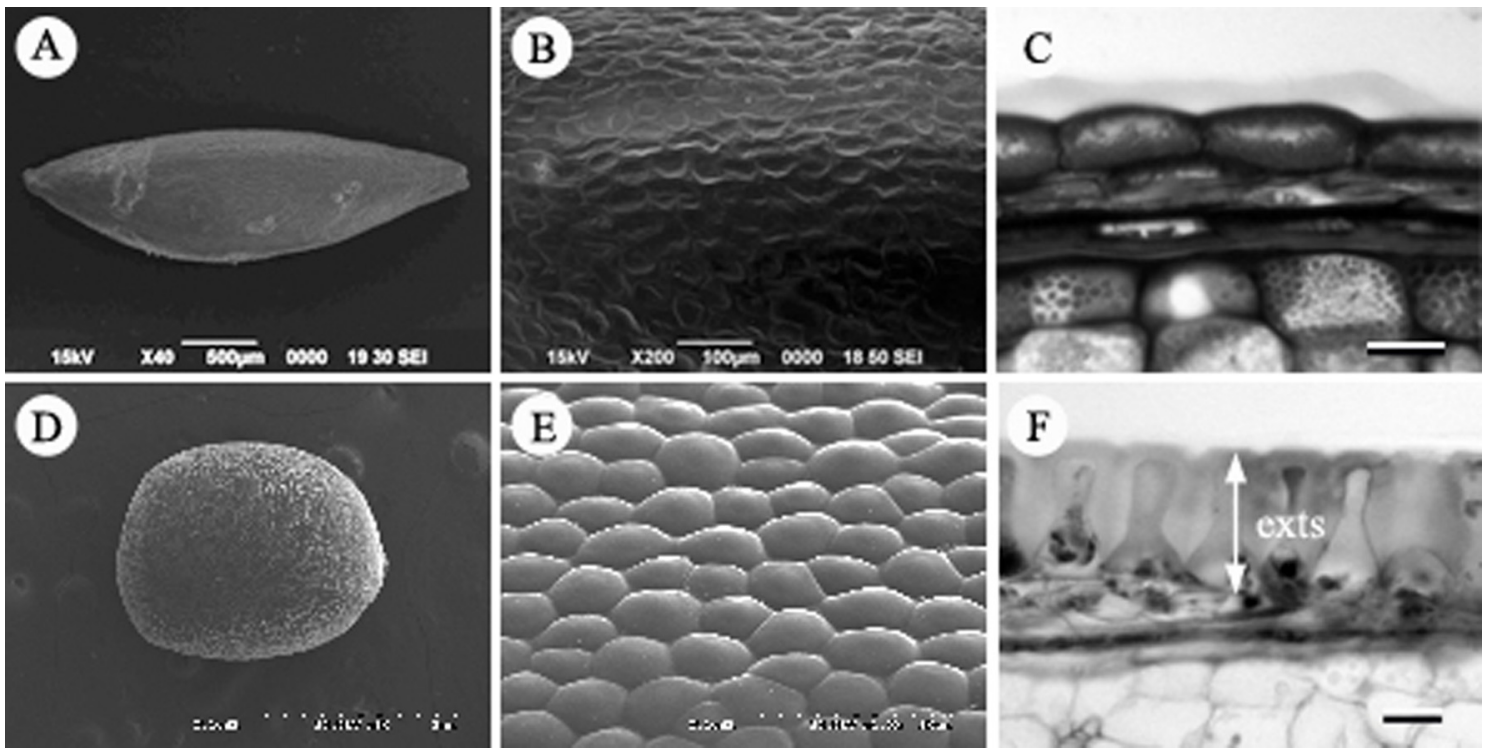

Fig. 5. Seed, seed surface and seed coat structure in Korean Ranunculaceae. A-C. Thalictrum uchiyamai. D-F. Trollius ledebourii. exts, exotesta. Scale bars $=50 \mu \mathrm{m}$. 
바람꽃속(Anemone L.): 뀡의바람꽃(A.raddeana), 홀아 비바람꽃(A. koraiensis), 바람꽃(A. narcissiflora) 3종을 관찰 하였다. 바람꽃속의 열매의 종류는 수과로 길이가 약 3$4 \mathrm{~mm}$, 폭은 약 1.8-2.2 mm의 크기로 대부분 타원형 또는
난형이었으며, 많은 털로 덮여있었다(Figs. 7A, D). 하지만, 바람꽃은 다른 종들과 달리 압축된 넓은 타원형의 형태로 가장자리에 날개를 가지며, 열매의 표면에는 털이 존재하 지 않는 고유형질을 가지고 있었다(Fig. $7 \mathrm{G}, \mathrm{H}$ ). 종피는 단
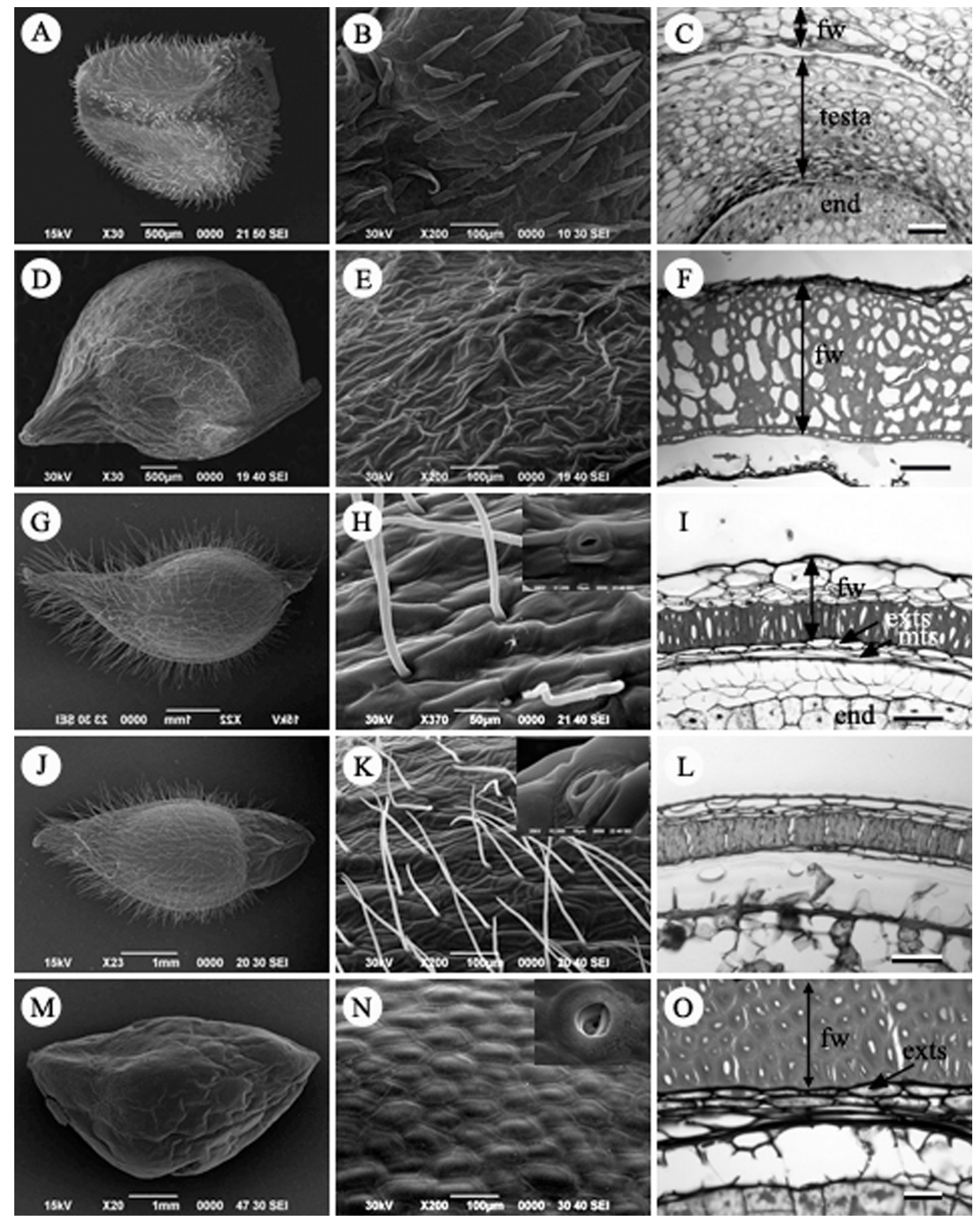

Fig. 6. Fruit, Fruit surface and seed coat structure in Korean Ranunculaceae. A-C. Adonis amurensis. D-F. Callianthemum insigne. G-I. Hepatica insularis. J-L. Hepatica asiatica. M-O. H. maxima. fw, fruit wall; end, endosperm; exts, exotesta; mts, mesotesta. Scale bars = $50 \mu \mathrm{m}$. 
주피성 배주로 외종피만 발달한다. 횡단면 구조를 보면, 외종피외층이 1-2개의 세포층으로 존재하는데 특징적인 세포형태로 발달하지 않는 unspecialized seed coat type이다. 외종피중층과 외종피내층은 압축되어 흔적만 남아있다
(Figs. 7C, F, I).

으아리속(Clematis L.): 참으아리(C. terniflora)와 으아 리(C. terniflora var. mandshurica)를 관찰하였다. 열매의 종류는 수과로 편평한 넓은 타원형으로 억센 털과 딱딱
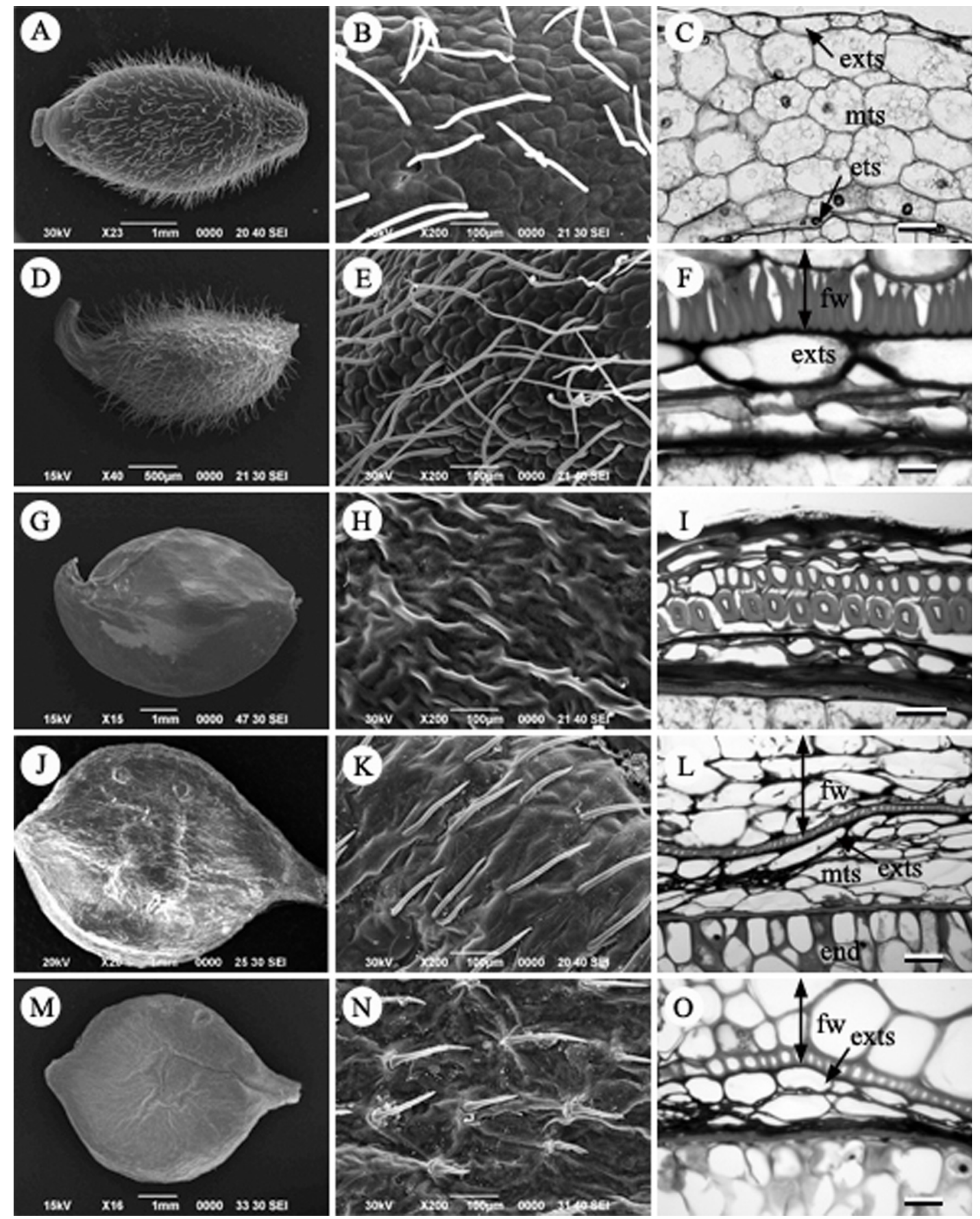

Fig. 7. Fruit, Fruit surface and seed coat structure in Korean Ranunculaceae. A-C. Anemone koraiensis. D-F. A. raddeana. G-I. A. narcissiflora. J-L. Clematis terniflora var. mandshurica. M-O. C. terniflora. exts, exotesta; mts, mesotesta; ets, endotesta; fw, fruit wall; end, endosperm. Scale bars $=50 \mu \mathrm{m}$. 
한 과피를 갖는다. 열매의 크기는 길이 약 $6.5 \mathrm{~mm}$, 폭 $4.5 \mathrm{~mm}$ 이고, 열매의 표면은 매끈하다(Figs. 7J, K, M, N). 내과피는 한 층의 후벽세포층으로 잘 발달하였다. 으아 리속은 외종피만으로 구성되는 단주피성 배주이다. 종자 의 횡단면은 외종피외층이 한 층의 세포층으로 약간 신 장하는 특징이 있으나, 외종피내층이 짙은 갈색의 섬유 상 세포층으로 발달하므로 종피는 외종피내층형이다 (Figs. 7L, O).

할미꽃속(Pulsatilla Miller): 할미꽃(P. koreana)과 동강할 미꽃(P. tongkangensis) 2종을 관찰하였다. 할미꽃속은 수 과로 길이는 약 $3.5-4.0 \mathrm{~mm}$, 폭은 $1.0-1.8 \mathrm{~mm}$ 의 크기로 긴 타원형이다. 열매 표면 전체에 긴 털이 빽빽하게 덮여 있 으며, 표피세포가 함몰된 형태이다(Figs. $8 \mathrm{~A}, \mathrm{~B}, \mathrm{D}, \mathrm{E})$. 과피
벽은 내과피가 한 층의 후벽세포로 뚜렷하게 발달하는 특 징이 있다(Figs. 8C, F). 배주는 단주피성이다. 횡단면은 외 종피외층과 외종피중층은 압축되거나 흔적만 남아있으 며, 외종피내층은 종단 방향으로 신장된 세포층으로 존재 하는 외종피내층형이다(Figs. $8 \mathrm{C}, \mathrm{F}$ ).

미나리아재비속(Ranunculus L.): 미나리아재비(R. japonica) 와 왜젓가락나물(R. uelpaertensis)을 관찰하였다. 열매의 종류는 수과로 길이 약 2.5-4.0 mm, 폭 1.8-2.2 mm 정도이 며, 편평한 달걀형으로 털은 있거나 없다. 열매의 표면은 전체적으로 평탄하며, 표피세포는 망상구조를 나타낸다 (Figs. 8G, H, J, K). 배주는 단주피성이다. 외종피내층형으 로 외종피내층이 얇은 한 층의 cuboid 상의 세포층을 이루 며, 나머지 층은 퇴화하였다(Figs. 8I, L).
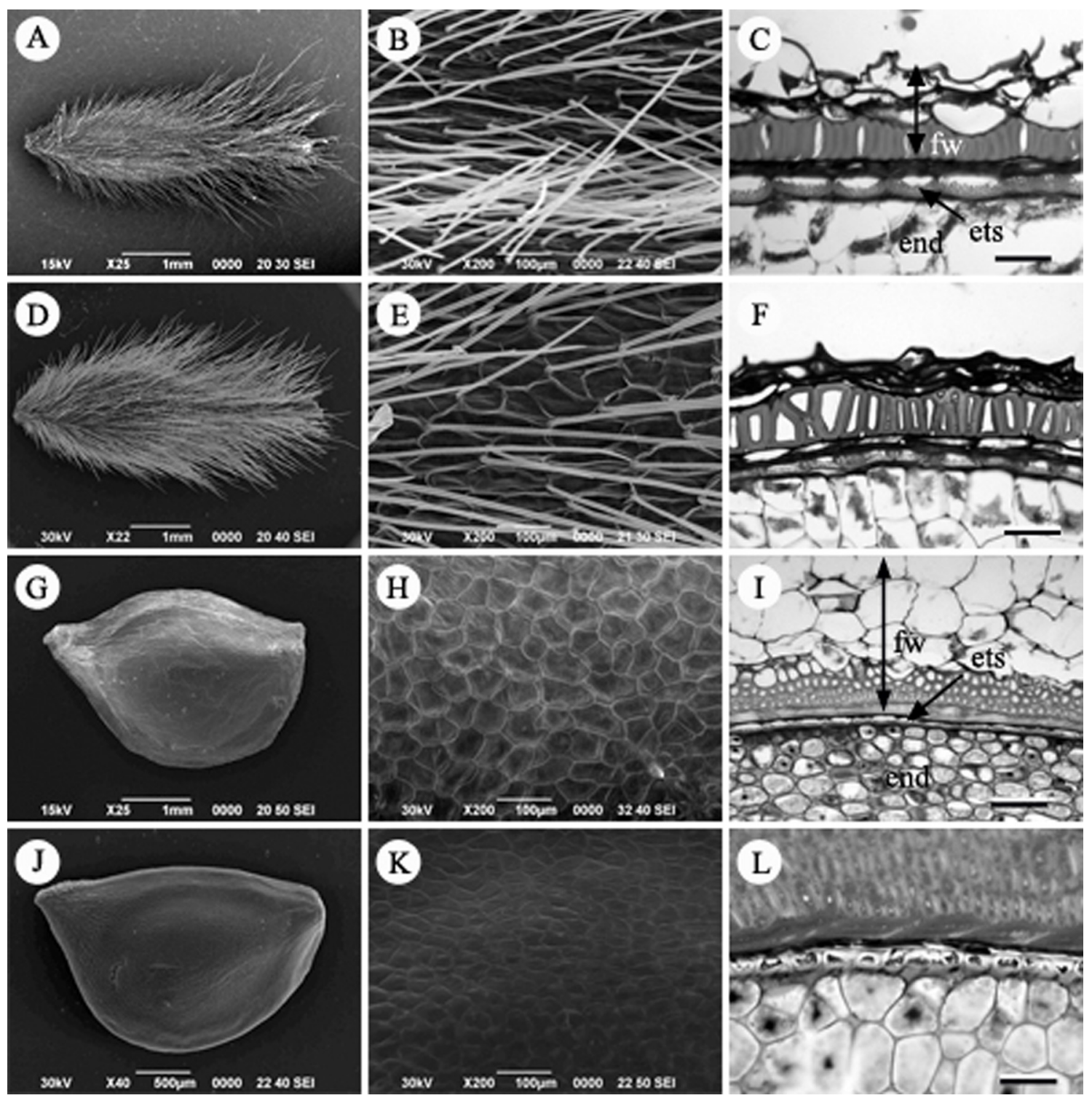

Fig. 8. Fruit, Fruit surface and seed coat structure in Korean Ranunculaceae. A-C. Pulsatilla koreana. D-F. P. tongkangensis. G-I. Ranunculus quelpaertensis. J-L. R. japonicus. fw, fruit wall; ets, endotesta; end, endosperm. Scale bars $=50 \mu \mathrm{m}$. 


\section{Subfamily Thalictroideae Heintze}

꿍의다리속(Thalictrum L.): 뀡의다리(T. aquilegifolium var. sibiricum), 금꿩의다리(T. rochebrunianum var. grandisepalum), 자주꿩의다리(T.uchiyamai), 산뀡의다리 (T. filamentosum var. tenerum) 등 4종을 관찰하였다. 과피 의 해부구조는 관찰하지 못하였으며, 종자는 긴 타원형 으로 길이는 약 $3.5-4.5 \mathrm{~mm}$, 폭은 $0.8-1.4 \mathrm{~mm}$ 이며(Figs.
$4 \mathrm{G}, \mathrm{J}, \mathrm{M}, 5 \mathrm{~A}$ ), 종자의 표면은 매끈하여 털이 없다(Figs. $4 \mathrm{H}, \mathrm{K}, \mathrm{N}, 5 \mathrm{~B})$. 내주피와 외주피를 가지는 양주피성 배주 이다. 외종피외층이 약간 신장하는 한 층의 세포층으로 발달하고 tannin을 함유하고 있는 외종피외층형이다 (Figs. 4I, L, O, 5C). 내종피층(mesotegmen)은 퇴화하였다. Table 2에 과피 및 종피 구조 관찰 결과를 종합적으로 정 리하였다.

Table 2. Comparisons of mature fruit and seed morphology of the Korean Ranunculaceae.

\begin{tabular}{|c|c|c|c|c|c|c|c|c|}
\hline \multirow{2}{*}{ Taxa } & \multicolumn{3}{|c|}{ Fruit } & \multicolumn{5}{|c|}{ Seed } \\
\hline & Type & Surface & Endocarp & Surface & Integuments & Testa & Tegmen & Seed coat type \\
\hline \multicolumn{9}{|l|}{ Subfamily Helleboroideae Hutch. } \\
\hline Aconitum pseudolaeve & Follicle & - & - & $\begin{array}{l}\text { Winged and } \\
\text { granulate }\end{array}$ & Bitegmic & $\begin{array}{l}\text { Endotesta } \\
\text { cuboid }\end{array}$ & Crushed & Endotestal \\
\hline Aconitum longecassidatum & Follicle & - & - & $\begin{array}{l}\text { Winged and } \\
\text { granulate }\end{array}$ & Bitegmic & $\begin{array}{l}\text { Endotesta } \\
\text { cuboid }\end{array}$ & Crushed & Endotestal \\
\hline Aconitum ciliare & Follicle & - & - & $\begin{array}{l}\text { Winged and } \\
\text { granulate }\end{array}$ & Bitegmic & $\begin{array}{l}\text { Endotesta } \\
\text { cuboid }\end{array}$ & Crushed & Endotestal \\
\hline Actaea asiatica & Baccate & - & - & $\begin{array}{l}\text { Finely } \\
\text { reticulate }\end{array}$ & Bitegmic & $\begin{array}{l}\text { Exotesta } \\
\text { elongated }\end{array}$ & Crushed & Exotestal \\
\hline Caltha palustris var. palustris & Follicle & - & - & Smooth & Bitegmic & $\begin{array}{c}\text { Exotesta } \\
\text { cuboid }\end{array}$ & Crushed & Exotestal \\
\hline Cimicifuga simplex & Follicle & - & - & $\begin{array}{l}\text { Winged and } \\
\text { granulate }\end{array}$ & Bitegmic & $\begin{array}{l}\text { Exotesta } \\
\text { elongate }\end{array}$ & Crushed & Exotestal \\
\hline Cimicifuga dahurica & Follicle & - & - & $\begin{array}{l}\text { Winged and } \\
\text { granulate }\end{array}$ & Bitegmic & $\begin{array}{l}\text { Exotesta } \\
\text { elongate }\end{array}$ & Crushed & Exotestal \\
\hline Cimicifuga heracleifolia var. heracleifolia & Follicle & - & - & $\begin{array}{l}\text { Winged and } \\
\text { granulate }\end{array}$ & Bitegmic & $\begin{array}{l}\text { Exotesta } \\
\text { elongate }\end{array}$ & Crushed & Exotestal \\
\hline Delphinium maackianum & Follicle & - & - & $\begin{array}{l}\text { Winged and } \\
\text { granulate }\end{array}$ & Bitegmic & $\begin{array}{l}\text { Endotesta } \\
\text { cuboid }\end{array}$ & Crushed & Endotestal \\
\hline Eranthis stellata & Follicle & - & - & Wrinkled & Unitegmic & $\begin{array}{l}\text { Exotesta } \\
\text { elongate }\end{array}$ & - & Exotestal \\
\hline Eranthis byunsanensis & Follicle & - & - & $\begin{array}{l}\text { Wrinkled and } \\
\text { unicellularhair }\end{array}$ & Unitegmic & $\begin{array}{l}\text { Exotesta } \\
\text { elongate }\end{array}$ & - & Exotestal \\
\hline Megaleranthis saniculifolia & Follicle & - & - & Smooth & Bitegmic & $\begin{array}{l}\text { Exotesta } \\
\text { sclereid }\end{array}$ & Crushed & Exotestal \\
\hline Trollius ledebourii & Follicle & - & - & Smooth & Bitegmic & $\begin{array}{c}\text { Exotesta } \\
\text { sclereid }\end{array}$ & Crushed & Exotestal \\
\hline \multicolumn{9}{|l|}{ Subfamily Isopyroideae Tamura } \\
\hline Aquilegia buergeriana var. oxysepala & Follicle & - & - & Smooth & Bitegmic & $\begin{array}{c}\text { Exotesta } \\
\text { sclereid }\end{array}$ & Crushed & Exotestal \\
\hline Aquilegia japonica & Follicle & - & - & Smooth & Bitegmic & $\begin{array}{l}\text { Exotesta } \\
\text { sclereid }\end{array}$ & Crushed & Exotestal \\
\hline Enemion raddeanum & Follicle & - & - & Wrinkled & Unitegmic & $\begin{array}{l}\text { Non- } \\
\text { sclereid }\end{array}$ & - & Exotestal \\
\hline Isopyrum manshuricum & Follicle & - & - & Smooth & Bitegmic & $\begin{array}{c}\text { Exotesta } \\
\text { sclereid }\end{array}$ & Crushed & Exotestal \\
\hline Semiaquilegia adoxoides & Follicle & - & - & Granulated & Bitegmic & $\begin{array}{c}\text { Exotesta } \\
\text { sclereid }\end{array}$ & Crushed & Exotestal \\
\hline
\end{tabular}


Table 2. Continued.

\begin{tabular}{|c|c|c|c|c|c|c|c|c|}
\hline \multirow{2}{*}{ Таха } & \multicolumn{3}{|c|}{ Fruit } & \multicolumn{5}{|c|}{ Seed } \\
\hline & Type & Surface & Endocarp & Surface & Integuments & Testa & Tegmen & Seed coat type \\
\hline \multicolumn{9}{|l|}{ Subfamily Ranunculoideae Hutch. } \\
\hline Adonis amurensis & Achene & $\begin{array}{l}\text { Hair and } \\
\text { stoma }\end{array}$ & Sclereid & - & Bitegmic & Unspecial & Crushed & Unspecialized \\
\hline Anemone raddeana & Achene & No hair & Sclereid & - & Unitegmic & Unspecial & - & Unspecialized \\
\hline Anemone koraiensis & Achene & No hair & Sclereid & - & Unitegmic & Unspecial & - & Unspecialized \\
\hline Anemone narcissiflora & Achene & No hair & Sclereid & - & Unitegmic & Unspecial & - & Unspecialized \\
\hline Callianthemum insigne & Achene & Hair & Sclereid & - & $?$ & $?$ & $?$ & $?$ \\
\hline Clematis terniflora var. mandshurica & Achene & Short hair & Sclereid & - & Unitegmic & $\begin{array}{l}\text { Endotesta } \\
\text { fiberous }\end{array}$ & - & Endotestal \\
\hline Clematis terniflora & Achene & Short hair & Sclereid & - & Unitegmic & $\begin{array}{l}\text { Endotesta } \\
\text { fiberous }\end{array}$ & - & Endotestal \\
\hline Hepatica asiatica & Achene & $\begin{array}{l}\text { Hair and } \\
\text { stoma }\end{array}$ & Sclereid & - & Unitegmic & Unspecial & - & Unspecialized \\
\hline Hepatica insularis & Achene & $\begin{array}{l}\text { Hair and } \\
\text { stoma }\end{array}$ & Sclereid & - & Unitegmic & Unspecial & - & Unspecialized \\
\hline Hepatica maxima & Achene & Stoma & Sclereid & - & Unitegmic & Unspecial & - & Unspecialized \\
\hline Pulsatilla koreana & Achene & Long hair & Sclereid & - & Unitegmic & $\begin{array}{l}\text { Endotesta } \\
\text { elongate }\end{array}$ & - & Endotestal \\
\hline Pulsatilla tongkangensis & Achene & Long hair & Sclereid & - & Unitegmic & $\begin{array}{l}\text { Endotesta } \\
\text { elongate }\end{array}$ & - & Endotestal \\
\hline Ranunculus japonicus & Achene & No hair & Sclereid & - & Unitegmic & $\begin{array}{l}\text { Endotesta } \\
\text { cuboid }\end{array}$ & - & Endotestal \\
\hline Ranunculus quelpaertensis & Achene & No hair & Sclereid & - & Unitegmic & $\begin{array}{l}\text { Endotesta } \\
\text { cuboid }\end{array}$ & - & Endotestal \\
\hline \multicolumn{9}{|l|}{ Subfamily Thalictroideae Heintze } \\
\hline Thalictrum aquilegifolium var. sibiricum & Achene & Hair & Sclereid & - & Bitegmic & $\begin{array}{l}\text { Exotesta } \\
\text { elongate }\end{array}$ & Crushed & Exotestal \\
\hline Thalictrum uchiyamai & Achene & Hair & Sclereid & - & Bitegmic & $\begin{array}{l}\text { Exotesta } \\
\text { elongate }\end{array}$ & Crushed & Exotestal \\
\hline $\begin{array}{l}\text { Thalictrum rochebrunianum } \\
\text { var. grandisepalum }\end{array}$ & Achene & Hair & Sclereid & - & Bitegmic & $\begin{array}{l}\text { Exotesta } \\
\text { elongate }\end{array}$ & Crushed & Exotestal \\
\hline Thalictrum filamentosum var. tenerum & Achene & Hair & Sclereid & - & Bitegmic & $\begin{array}{l}\text { Exotesta } \\
\text { elongate }\end{array}$ & Crushed & Exotestal \\
\hline
\end{tabular}

\section{고 찰}

한국산 미나리아재비과 20속에 대하여 열매 및 종자형 태에 기초한 분류학적 연구를 수행하였다.

미나리아재비과는 열매의 종류를 기준으로 골돌과와 수과로 크게 나눠지고, 노루삼이 장과로 나타난다. 따라 서 분류의 첫 단계에서 열매의 종류와 염색체의 형태(Rtype vs. T-type)로 분류하면 기존의 분류체계에 대부분 일 치한다. 본 연구에서는 아직 알려지지 않은 열매와 종자 의 해부형태를 조사하여 분류학적으로 유용한 형태형질 을 찾고 이들 형질들의 분류학적으로 이용 가능성을 확
인하고자 하였다(Table 2).

\section{열매의 종류}

한국산 미나리아재비과는 열매의 종류가 골돌과와 수 과로 크게 대별되고, 노루삼속만이 장과로 나타난다. 열 매의 종류 형질은 이미 여러 학자들에 의해 밝혀졌다 (Tamura, 1993).

\section{열매 표면의 형태}

조사된 분류군의 열매 표면 형질로는 털의 존재여부, 돌 기물의 존재여부, 기공의 존재여부 등이 분류형질로 선발 
되었다. 수과형태를 갖는 미나리아재비아과와 꿩의다리 아과에 대하여 열매 표면을 조사한 결과, 뀡의다리아과는 표면에 털이 존재하는 특징을 공유하였고, 미나리아재비 아과는 털이 있는 것과 없는 것이 함께 나타났다. Park and Park (2008)은 뀡의다리속을 연구하면서 자방의 표면에 털 의 유형에 따라 3 가지로 나누었다. 즉, 자방 표면에 털이 없는 것, 자방에 선모가 존재하는 것, 자방에 선모와 연모 가 동시에 존재하는 것으로 구분하였다. 또한 과병의 유 무, 능선과 날개의 형태로 열매를 분류하면서 과피의 형 질이 절 이하의 분류군에 유용함을 제시하였다.

\section{열매 표면 털}

열매 표면에 털이 존재하지 않는 것과 선모로 발달하는 것, 연모로 길게 또는 짧게 발달하는 특징이 관찰되었다. 수과를 갖는 분류군 중에서 Anemone속과 Ranunculus속에 서 털이 없는 것으로 나타났다. 그러나 노루귀속 (Hepatica)에서는 섬노루귀가 털이 없으며, 나머지 두 종 은 털이 존재하였다. 또한 뀡의다리속(Park and Park, 2008) 에서도 털이 없는 것과 선모 또는 연모로 발달하는 분류 군이 동시에 나타났다. 따라서 열매 표면의 털 형질에 대 하여는 속 수준에서는 유용성이 없고, 종 이하 분류군에 서는 유용하게 적용될 수 있다고 생각한다.

\section{열매 표면 기공}

조사결과 열매 표면에 비기능성 기공이 발달하는 특징 이 복수초속과 노루귀속에서 관찰되었다. Lee et al. (2003) 은 복수초속을 연구하면서 복수초는 열매 표면에 기공이 없는 특징으로 근연분류군과 구분하였으나, Son and Ko (2013)는 복수초속의 수과 형태를 연구하여 조사한 분류 군 모두에서 기공이 존재하는 특징을 밝혀 기존의 기공유 무에 따라 속내 분류군을 구분하기에는 무리가 있을 것이 라 하였다. 본 연구에서는 복수초를 관찰한 결과 Son and Ko (2013)의 결과와 일치하였다.

\section{과피 해부형태}

수과 형태를 갖는 미나리아재비아과에 대하여 과피를 해부한 결과 내과피가 보호기능을 하는 후벽세포층으로 발달하는 특징을 확인하였다. 본 연구에서는 뀡의다리속 의 과피 구조는 확인하지 못하였으나, 조사한 모든 분류군 에서 발달정도의 차이는 있으나 내과피가 한 층의 후벽세 포(sclereid cell)로 발달하였다. 그러나 복수초속은 내과피 가 후벽세포로 발달하지 않아 아과 수준에서 변이가 관찰 되었다. 이것은 Cai et al. (2009)의 연구결과를 강하게 지지 하여 복수초속의 분류학적 위치를 재검토할 필요가 있다.

\section{종자의 종피 구성}

미나리아재비과는 양주피성과 단주피성 배주가 함께 나타난다. 꿩의다리아과는 아과 수준에서 모두 양주피성
배주이다. 그러나 미나리아재비아과의 대부분의 분류군 은 단주피성 배주인데 반하여, 복수초속은 양주피성을 나 타낸다. 또한 나도바람꽃속도 Isopyroideae아과에서 유일하 게 단주피성 배주 형태를 나타내고 있다. 이것은 아과 내에 서 변이가 보이나 속 수준에서는 유용한 형질로 판단된다. Cai et al. (2009)은 미나리아재비과의 ITS분석을 통하여 복 수초속이 미나리아재비아과에 위치하지만 Helleboroideae 아과로 옮겨야 한다고 보고하였다. 본 연구에서도 양주피 성 배주를 갖는 속은 미나리아재비아과에서 제외해야 할 것으로 판단되었다. 그러나 Helleboroideae아과에서도 너 도바람꽃속이 유일하게 단주피성 배주를 갖는 속으로 나 타나므로 좀 더 정확한 연구가 필요하다고 생각한다.

\section{종피의 형태}

종피구조는 Corner (1976)에 의해 6가지로 분류된다. Isopyroideae아과와 Thalictroideae아과는 모두 외종피외층 형이었다. 그러나 Helleboroideae아과와 Ranunculoideae아 과는 아과 내에서 다양하게 나타났다. 즉, (1) 외종피외층 형-Caltha, Megaleranthis, Trollius, (2) 외종피내층형Aconitum, Clematis, Delpinium, Pulsatila, Ranunculus, (3) unspecialized type-Adonis, Anemone, Hepatica 속으로 구분 되었다. 따라서 Helleboroideae아과와 Ranunculoideae아과 에서는 종피의 형태가 분류학적으로 유용하게 활용될 수 있을 것이다.

\section{종피 표면}

종피 표면 형태나 무늬, 모용 등이 관찰되었다. 진범속, 승마속, 제비고깔속에서는 외종피외층이 날개로 발달하 는 외종피외층형으로 종피 표면에 미세돌기가 함께 존재 하여 다른 속과 구별되는 형질로 확인되었다. 특히, 진범 속과 제비고깔속은 대부분의 형질을 공유하며, 특히 종피 표면의 미세형질과 횡단면 구조에서 공통점을 가진다. 동 의나물속, 모데미풀속, 금매화속은 종자가 검고, 표면 형 태가 매끈하며, 표피세포가 입방형으로 발달하였다. 종피 의 외종피외층은 한 층의 대보강세포형의 후벽세포로 발 달하는 특징이 있다. 너도바람꽃속의 종피 형태는 표면이 주름이 지는 형(너도바람꽃)과 표면에 단세포 모용이 발 달하는 특징이 관찰되었다. 단세포 모용의 발달 형질은 기존의 형태적 특징 외에 변산바람꽃을 한국 특산종으로 강하게 지지할 수 있는 형태적 특징이라고 생각된다(Jung et al., 2010). 개구리발톱의 종자에서는 표피가 발달하여 혹과 같은 형태를 가지는 특징을 확인하였다.

만주바람꽃속(Isopyrum)의 만주바람꽃 종피형태는 외 종피외층이 단보강세포형의 후벽세포로 발달하는 특징 을 나타내어, 개구리발톱, 매발톱꽃, 금매화속 등의 종피 구조와 동일하였다. 나도바람꽃의 종피는 단주피성으로 외종피외층 세포가 뚜렷하게 장타원형의 형태를 나타내 어, 단주피성 배주를 갖는 너도바람꽃속의 종피구조와 매 


\section{우 유사하였다.}

Compton et al. (1998)은 형태형질과 분자형질(ITS, cpDNA)을 기초로 노루삼속과 승마속, Souliea속의 계통유 연관계를 보고하면서 노루삼속이 승마속과 단계통을 이 루어 승마속으로 포함시키는 것을 지지하였다. 그러나 열 매의 종류가 골돌과와 장과로 뚜렷하게 구별되는 형질이 있으므로 본 연구의 결과와는 일치하지 않는다. Wang et al. (2010)은 형태형질과 분자형질을 증거로 아시아 고유 종인 Calathodes와 모데미풀속의 계통학적 위치를 보고하 면서 모데미풀속은 금매화속에 유집되기에 금매화속에 통합해야 한다고 주장하였다. 본 연구에서도 금매화속과 모데미풀속의 종자해부형태가 한 층의 대보강세포를 갖 는 외종피외층형으로 나타나므로 모데미풀속이 금매화 속에 통합되는 것을 지지한다.

연구결과를 Tamura (1993)의 분류체계와 비교해 보면, 미나리아재비아과의 복수초속은 양주피성 배주이므로 Helleboroideae아과로 분류되어야 할 것이며, Cai et al. (2009)의 연구결과에서도 복수초속은 금매화속과 근연인 것으로 나타났다. 또한 나도바람꽃속은 단주피성 배주이 므로 Isopyroideae아과에서 분리하여 Helleboroideae아과로 위치시키는 것이 타당할 것으로 생각된다.

이상과 같이 한국산 미나리아재비과의 열매 및 종자 형 태를 조사한 결과, 아과 수준에서 유용한 형질은 열매의 종류와 내과피가 한 층의 후벽세포로 발달한다는 특징(수 과 분류군)을 사용할 수 있고, 속 수준에서의 분류형질로 는 열매 표면 모용, 열매표면에 기공 유무, 종피 구성(양주 피성 vs. 단주피성), 종피 type, 종피 표면 세포모양 등이 유 용하게 활용될 수 있을 것이다.

한편, 한국산 미나리아재비과의 열매 및 종자의 연구 결 과, 노루삼(Actaea asiatica)과 매화바람꽃(Callianthemum insigne)의 분류학적 위치에 대하여 보다 정확한 연구가 필 요하다고 생각된다.

\section{Acknowledgments}

This study was supported by 2015 Research Grant from Kangwon National University (No. 520150108). The authors thank two anonymous reviewers for their valuable comments on this manuscript.

\section{Literature Cited}

Cai, Y., S. Li, Y. Liu, S. Quan, M. Chen, Y. Xie, H. Jiang, E. Wei, N. Yin, L. Wang, R. Zhang, C. Huang, X. He and M. Jiang. 2009. Molecular phylogeny of Ranunculaceae based on internal transcribed spacer sequences. African Journal of Biotechnology 8: 5215-5224.

Cai, Y., S. Li, M. Chen, M. Jiang, Y. Liu, Y. Xie, Q. Sun, H. Jiang,
N. Yin, L. Wang, R. Zhang, C. Huang and K. Lei. 2010. Molecular phylogeny of Ranunculaceae based on $r b c \mathrm{~L}$ sequences. Biologia 65: 997-1003.

Compton, J. A., A. Culham and S. L. Jury. 1998. Reclassification of Actaea to include Cimicifuga and Souliea (Ranunculaceae): Phylogeny inferred from morphology, nrDNA ITS, and cpDNA trnL-F sequence variation. Taxon 47: 593-634.

Corner, E. J. H. 1976. The Seeds of Dicotyledons. 2 vols. Cambridge University Press, Cambridge, Vol. 1, 311 pp, Vol. 2, $552 \mathrm{pp}$.

Hegnauer, R. 1966. Comparative phytochemistry of alkaloids. In Comparative Phytochemistry. Swain T. (ed.), Academic Press, London. Pp. 211-230.

Heo, K. and Y. Suh. 2008. Taxonomic implications of seed coat in the subtribe Calthinae (Ranunculaceae). Korean Journal of Plant Taxonomy 38: 1-16.

Hoot, S. B. 1991. Phylogeny of the Ranunculaceae based on epidermal microcharacters and macromorphology. Systematic Botany 16: 741-755.

Hoot, S. B. 1995. Phylogeny of the Ranunculaceae based on preliminary $a t p \mathrm{~B}, r b c \mathrm{~L}$ and $18 \mathrm{~S}$ nuclear ribosomal DNA sequence data. Plant Systematics and Evolution [Supplement] 9: 241-251.

Johansson, J. T. 1995. A revised chloroplast DNA phylogeny of the Ranunculaceae. Plant Systematics and Evolution [Supplement] 9: 253-261.

Johansson, J. T. and R. K. Jansen. 1993. Chloroplast DNA variation and phylogeny of the Ranunculaceae. Plant Systematics and Evolution 187: 29-49.

Jung, W.-C., D.-Y. Shin and K. Heo. 2010. Comparative seed morphology of Korean Eranthis (Ranunculaceae). Korean Journal of Plant Taxonomy 40: 105-107. (in Korean)

Langlet, O. 1932. Über chromosomenverhältnisse und systematik der Ranunculaceae. Svensk Botanisk Tidskrift 26: 381-400.

Lee, C., S. Lee, Y. Suh, S.-H. Yeah and N. S. Lee. 2003. A morphological reexamination on the genus Adonis L. sensu lato (Ranunculaceae) in Korea. Korean Journal of Plant Taxonomy 33: 435-454. (in Korean)

Mabberley, D. J. 2008. Mabberley's Plant-Book. A Portable Dictionary of Plants, Their Classification and Uses. 3rd ed. Cambridge University Press, Cambridge, $1040 \mathrm{pp}$.

Nowicke, J. W. and J. J. Skvarla. 1979. Pollen morphology: the potential influence in high order systematics. Annals of Missouri Botanical Garden 66: 633-700.

Park, C. W., S. H. Yeau, C. S. Chang, H. Y. Lee and B. Y. Sun. 2007. Ranunculaceae Juss. In The Genera of Vascular Plants of Korea. Park, C.-W. (ed.), Academy Publishing Co., Seoul. Pp. 165-205. 
Park, S.-J. and S.-J. Park. 2008. The morphology of Thalictrum L. in Korea. Korean Journal of Plant Taxonomy 38: 433-458. (in Korean)

Son, D. C. and S. C. Ko. 2013. Aggregated achenes and achene morphology of the Korean Adonis L. and its related taxa in East Asia. Korean Journal of Plant Taxonomy 43: 312-318. (in Korean)

Spjut, R. W. 1994. A systematic treatment of fruit types. Memoirs of the New York Botanical Garden 70: 1-182.
Tamura, M. 1993. Ranunculaceae. In The Families and Genera of Vascular Plants. Vol. II. Flowering Plant · Dicotyledons: Magnoliid, Hamamelid and Caryophyllid Families. Kubitzki, K., J. G. Rohwer and V. Bittrich (eds.), Springer-Verlag, Berlin. Pp. 563-583.

Wang, W., H. Hu, X.-G. Xiang, S.-X. Yu and Z.-D. Chen. 2010. Phylogenetic placements of Calathodes and Megaleranthis (Ranunculaceae): Evidence from molecular and morphological data. Taxon 59: 1712-1720. 